\title{
Effect of organic and inorganic sources of nutrients on rice crop
}

\author{
Mohana Rao Puli', PRK Prasad ${ }^{2}$, P Ravindra $\mathrm{Babu}^{3}, \mathrm{M}^{1}$ Jayalakshmi ${ }^{4}$ and Srihari Rao Burla ${ }^{5}$ \\ Agricultural College, Bapatla, Guntur, Andhra Pradesh--522101 \\ *Corresponding author e-mail: mohanpuli007@gmail.com
}

Received : 22 January 2016

Accepted : 20 April 2016

Published : 20 July 2016

\begin{abstract}
An experiment was conducted for two consecutive years (2011-2012 and 2012-2013) on fine texture soils of Agricultural college farm, Bapatla. The experiment was laid out in a randomized block design in wet season with four treatments and five replications. The treatments consisted of $M_{1}$ (recommended dose of fertilizers $(R D F)$ - Control), $M_{2}\left(10 t\right.$ farmyard yard manure $\left.(F Y M) h a^{-1}+R D F\right), M_{3}\left(1.5 t\right.$ vermicompost ha $\left.{ }^{-1}+R D F\right), M_{4}$ (Green manuring + RDF). Data collected on biometric observations (plant height, number of tillers, dry matter accumulation) and yield. The yield of crop was significantly increased with the application of $100 \% N P K$ in combination with FYM @ 10t ha . $^{-1}$ However, it was at par with green manuring along with the application of $100 \%$ RDF (NPK).Thus, green manure in situ with Dhaincha may be used as an alternative organic source of nutrients to the FYM.
\end{abstract}

Key words: Inorganic sources, organic sources, plant height, rice crop

Rice (Oryza sativa L.) is one of the important cerealin world as well as in India. Among several management practices that affect soil quality, fertilizer application is of paramount importance for its role in growth and development of the crop. In intensive agriculture with high yielding varieties, crop yields have adverse effect on soil health. Hence, it is time to pay serious attention to nutrient management. The integrated use of organic manures and inorganic fertilizers can help to maintain optimum crop yields and long term soil productivity. There is a vast scope for increasing nutrient supply through use of organic manures and adoption of proper cropping system, which together can contribute significantly to the required nutrient pool.

The high cost of fertilizers and unstable crop production call for substituting part of the inorganic fertilizers by locally available low cost organic sources like FYM, green manuring and vermicompost in an integrated manner is essential for sustainable production. Integrated nutrient management involving conjunctive use of organic, inorganic and crop residues may improve the soil productivity (Patra et al. 2000) and system productivity may become sustainable (Raju and Reddy, 2001).

\section{MATERIALS AND METHODS}

The balanced fertilization through integrated use of manures and fertilizers has been found useful in various crops. In order to investigate the influence of different sources of nutrients on rice crop, the present experiment was conducted in the field number 49A and 49B of the Agricultural College Farm, Bapatla, during the years 2011-12 and 2012-13, respectively. The results of the initial soil analytical data indicated that the experimental soil is clayeytexture, slightly alkaline in reaction, low in organic carbon $(0.51 \%)$ and available nitrogen $(168 \mathrm{~kg}$ $\left.\mathrm{ha}^{-1}\right)$, and high in available phosphorus $\left(94.6 \mathrm{~kg} \mathrm{P}_{2} \mathrm{O}_{5}\right.$ $\mathrm{ha}^{-1}$ ) and potassium (943 $\left.\mathrm{kg} \mathrm{K}_{2} \mathrm{O} \mathrm{ha}^{-1}\right)$.

The experiment consisted of four treatments viz., $\mathrm{M}_{1}$ (RDF - Control), $\mathrm{M}_{2}\left(10 \mathrm{t} \mathrm{FYM} \mathrm{ha}^{-1}+\mathrm{RDF}\right)$, $\mathrm{M}_{3}$ (1.5t vermicompost ha $\left.{ }^{-1}+\mathrm{RDF}\right), \mathrm{M}_{4}$ (Green manuring + RDF). The experiment was laid out in $\mathrm{RBD}$ and replicated five times. The recommended fertilizer dose was applied as 160:40:40 kg N, $\mathrm{P}_{2} \mathrm{O}_{5}$ and $\mathrm{K}_{2} \mathrm{O}$ $\mathrm{ha}^{-1}$. 
A popular super fine rice cultivar BPT 5204 (Samba Mashuri) was selected for wet season. It is a cross between (GEB-24 x TN-1) and Mahsuri. FYM and vermicompost were added 7 days before transplanting of rice on dry weight basis. Dhaincha crop was raised with the seed rate of $60 \mathrm{~kg} \mathrm{ha}^{-1}$ in individual plots and it was incorporated 7 days before transplanting of rice as green manure at flowering stage. Nitrogen was applied in the form of urea in three splits (transplanting, 30 days after transplanting and 60 days after transplanting). Phosphorus was applied in the form of single super phosphate as basal dose before transplanting. Potassium was applied in the form of muriate of potash in two splits, first split as basal before transplanting and second split at 60 DAT. The nutrient content in organic applied during 2011-12 and 2012-13 is presented as Table 1 and Table 2 .

Five hills were randomly selected for recording plant morphological parameters (Plant height, number of tillers per hill, dry matter accumulation) at 30,60 and 90 days after transplanting and at maturity. The samples were dried in shade and then dried in hot-air oven at $65^{\circ} \mathrm{C}$ tillit attains constant weight. The mean dry weight was multiplied by number of hills $\mathrm{m}^{-2}$ and expressed in $\mathrm{tha}^{-1}$.

The crop harvested from each net plot was bundled up separately and allowed for drying in sun and threshed individually plot-wise by using pedal operated paddy thresher. Cleaning of the grain was done after threshing and then dried in sun to a constant weight to record the final yield. Grain yields from the labeled hills were added to the corresponding plot yields before expressing the final grain yield in $\mathrm{t} \mathrm{ha}^{-1}$ during both the years of study.Straw from the net plot of each treatment was dried in sun to a constant weight. The straw from the five labeled hills was included to their corresponding plot yields before expressing the final straw yield in $\mathrm{kg}$ $\mathrm{ha}^{-1}$ during both the years of the study.

\section{RESULTS AND DISCUSSION}

\section{Plant height}

Plant height measured at 30,60, and 90 DAT and maturity was significantly influenced by different organic sources of nutrients (Table 3).

Among the organic sources, application of $10 \mathrm{t}$ $\mathrm{FYM} \mathrm{ha}^{-1}+100 \%$ NPK $\left(\mathrm{M}_{2}\right)$ recorded maximum plant height at all the stages of sampling over other sources but statistically at par with each other. Plant height of rice measured at 30 and 60 DAT was significantly higher with the application of organic manures in combination with RDF $\left(\mathrm{M}_{2}, \mathrm{M}_{3}\right.$ and $\left.\mathrm{M}_{4}\right)$ over RDF alone $\left(\mathrm{M}_{1}\right)$. Chemical fertilizer offers nutrients which are readily soluble in soil solution and thereby instantly available to plants. Nutrient availability from organic sources is due to microbial action and improved physical condition of soil (Sarker et al. 2004). The increase in plant height in response to application of organic and chemical fertilizers was probably due to enhanced availability of nutrients (Mohana Rao et al. 2014).

Plant height measured at 90 DAT and maturity was significantly higher in the treatment $\mathrm{M}_{2}$ and $\mathrm{M}_{4}$ (green manuring $+100 \%$ NPK) compared to $M_{1}$ whereas, $\mathrm{M}_{1}$ was on par with $\mathrm{M}_{3}$ (vermincompost @ $1.5 \mathrm{t} \mathrm{ha}^{-1}+100 \%$ NPK). Sharma and Mittra (1988) observed an increase of $3 \mathrm{~cm}$ in the plant height of rice

Table 1. Nutrient content in organics applied during $1{ }^{\text {st }}$ year (2011-12)

\begin{tabular}{llllllllllll}
\hline Organics & $\% \mathrm{C}$ & $\% \mathrm{~N}$ & $\% \mathrm{P}_{2} \mathrm{O}_{5}$ & $\% \mathrm{~K}_{2} \mathrm{O}$ & $\% \mathrm{Ca}$ & $\% \mathrm{Mg}$ & $\begin{array}{c}\mathrm{Fe} \\
(\mathrm{ppm})\end{array}$ & $\begin{array}{l}\mathrm{Mn} \\
(\mathrm{ppm})\end{array}$ & $\begin{array}{l}\mathrm{Cu} \\
(\mathrm{ppm})\end{array}$ & $\begin{array}{l}\mathrm{Zn} \\
(\mathrm{ppm})\end{array}$ & $\begin{array}{l}\mathrm{C}: \mathrm{N} \\
\text { FYM }\end{array}$ \\
\hline Vermi compost & 12.54 & 1.80 & 0.81 & 0.72 & 2.38 & 0.67 & 627 & 262 & 180 & 45 & 6.97 \\
Dhaincha & 36.50 & 3.40 & 0.41 & 2.07 & 1.60 & 0.25 & 1008 & 144 & 22 & 42 & 10.74 \\
\hline
\end{tabular}

Table 2.Nutrient content in organics applied during $2^{\text {nd }}$ year (2012-13)

\begin{tabular}{llllllllllll}
\hline Organics & $\% \mathrm{C}$ & $\% \mathrm{~N}$ & $\% \mathrm{P}_{2} \mathrm{O}_{5}$ & $\% \mathrm{~K}_{2} \mathrm{O}$ & $\% \mathrm{Ca}$ & $\% \mathrm{Mg}$ & $\begin{array}{l}\mathrm{Fe} \\
(\mathrm{ppm})\end{array}$ & $\begin{array}{l}\mathrm{Mn} \\
(\mathrm{ppm})\end{array}$ & $\begin{array}{l}\mathrm{Cu} \\
(\mathrm{ppm})\end{array}$ & $\begin{array}{l}\mathrm{Zn} \\
(\mathrm{ppm})\end{array}$ & $\begin{array}{l}\mathrm{C}: \mathrm{N} \\
\text { FYM }\end{array}$ \\
\hline Vermi compost & 13.00 & 1.80 & 0.79 & 0.81 & 2.29 & 0.67 & 651 & 275 & 207 & 56 & 7.22 \\
Dhaincha & 40.00 & 3.30 & 0.40 & 2.67 & 1.63 & 0.25 & 1120 & 142 & 20 & 49 & 12.12 \\
\hline
\end{tabular}


Table 3. Influence of organics on plant height $(\mathrm{cm})$ at different growth periods of rice

\begin{tabular}{lllll}
\hline Treatment & \multicolumn{3}{l}{ Pooled data of two years } & \\
\cline { 2 - 5 } & 30 DAT & 60 DAT & 90 DAT & Maturity \\
\hline $\mathrm{M}_{1}$ - RDF (Control) & 49.1 & 73.1 & 81.5 & 82.9 \\
$\mathrm{M}_{2}$ - FYM 10t ha ${ }^{-1}+$ RDF & 54.8 & 80.4 & 90.2 & 91.2 \\
$\mathrm{M}_{3}$ - Vermicompost 1.5t ha ${ }^{-1}+\mathrm{RDF}$ & 54.0 & 78.9 & 87.7 & 88.8 \\
$\mathrm{M}_{4}$ - Green manuring + RDF & 54.2 & 79.3 & 89.1 & 90.0 \\
SEm \pm & 1.5 & 1.8 & 2.3 & 2.3 \\
CD $(\mathrm{P}<0.05)$ & 4.6 & 5.6 & 7.0 & 7.2 \\
$\mathrm{CV}(\%)$ & 6.2 & 5.2 & 5.8 & 5.7 \\
\hline
\end{tabular}

with the incorporation of dhaincha. The variation in plant height due to nutrient sources was considered to be due to variation in the availability of major nutrients. Azad and Lehria (2001) recorded the increased plant height with the application of FYM. Muhammad (2008) observed similar results with application of organic manure and compost in rice.

\section{Number of tillers $\mathbf{m}^{-2}$}

Data presented in Table 4 indicated that the number of tillers $\mathrm{m}^{-2}$ at allmost all growth stages was increased significantly with the application of organic manures along with RDF over RDF alone. These results were in conformity with the findings of Hemalatha et al. (2000). Organic sources offer more balanced nutrition to the plants, especially micro nutrients which positively affect number of tiller in plants (Miller 2007).

Number of tillers per $\mathrm{m}^{-2}$ was, maximum at 60 DAT than that at other stages. At this stage the tiller number was ranging from 451.5 to 535.5. Among the organic sources, FYM $\left(\mathrm{M}_{2}\right)$ application recorded maximum number of tillers per $\mathrm{m}^{-2}(505,535.5,513$ and 470 at 30, 60, 90 DAT and maturity, respectively) over other organic sources but on par with each other. Consequent upon the increased radiation interception as well as better nutrition of crop plants due to FYM application, might have increased the photosynthesis rate which was reflected is significant increase in the number of tillers per $\mathrm{m}^{2}$ at all the dates of observation (Singh and Mandal 1997).

Tillering is an important trait for grain production and is thereby an important aspect in rice yield. Mirza et al. (2010) reported increase in number of tillers in rice plants due to influence of different fertilizer combinations. According to them more number of tillers per square meter might be due to the more availability of nitrogen, which plays a vital role in cell division.

\section{Dry matter accumulation}

The results pertaining to dry matter accumulation at different stages are presented in the Table 5. Dry matter yield ranged from 1354 to 1670,6539 to 7669 and 8571 to $9953 \mathrm{~kg} \mathrm{ha}^{-1}$ at 30,60 and 90 DAT, respectively. Among the organic sources, FYM $\left(\mathrm{M}_{2}\right)$ application recorded maximum dry matter accumulation at all the stages of sampling over other sources (1670, 7669 and $9953 \mathrm{~kg} \mathrm{ha}^{-1}$ at 30, 60 and 90 DAT, respectively). It might be attributed to the FYM providing better growing conditions to plants by continuous supply of nutrients

Table 4.Influence of organics on number of tillers $\mathrm{m}^{-2}$ at different growth periods of rice

\begin{tabular}{lllll}
\hline \multirow{2}{*}{ Treatment } & \multicolumn{4}{c}{ Pooled data of two years } \\
\cline { 2 - 5 } & 30 DAT & 60 DAT & 90 DAT & Maturity \\
\hline $\mathrm{M}_{1}$ - RDF (Control) & 423.0 & 451.5 & 437.0 & 395.0 \\
$\mathrm{M}_{2}$ - FYM 10t ha ${ }^{-1}+\mathrm{RDF}$ & 505.0 & 535.5 & 513.0 & 470.0 \\
$\mathrm{M}_{3}$ - Vermicompost 1.5t ha ${ }^{-1}+\mathrm{RDF}$ & 479.0 & 505.5 & 489.0 & 455.5 \\
$\mathrm{M}_{4}-$ Green manuring + RDF & 488.0 & 510.5 & 492.5 & 462.0 \\
$\mathrm{SEm} \pm$ & 18.8 & 16.3 & 17.1 & 16.5 \\
$\mathrm{CD}(\mathrm{P}<0.05)$ & 57.5 & 50.0 & 52.5 & 49.0 \\
$\mathrm{CV}(\%)$ & 8.9 & 7.2 & 7.9 & 8.2 \\
\hline
\end{tabular}


Table 5. Influence of organics on dry matter accumulation $\left(\mathrm{kg} \mathrm{ha}^{-1}\right)$ at different growth periods of rice

\begin{tabular}{|c|c|c|c|}
\hline \multirow[t]{2}{*}{ Treatment } & \multicolumn{3}{|c|}{ Pooled data of two years } \\
\hline & 30 DAT & 60 DAT & 90 DAT \\
\hline $\mathrm{M}_{1}-\mathrm{RDF}$ (Control) & 1354 & 6539 & 8571 \\
\hline $\mathrm{M}_{2}-\mathrm{FYM} 10 \mathrm{tha} \mathrm{h}^{-1}+\mathrm{RDF}$ & 1670 & 7669 & 9953 \\
\hline $\begin{array}{l}\mathrm{M}_{3}^{2}-\text { Vermicompost } 1.5 \mathrm{tha}^{-1} \\
+\mathrm{RDF}\end{array}$ & 1590 & 7227 & 9515 \\
\hline $\mathrm{M}_{4}$ - Green manuring $+\mathrm{RDF}$ & 1651 & 7521 & 9752 \\
\hline SEm \pm & 37.8 & 178.4 & 247.4 \\
\hline $\mathrm{CD}(\mathrm{P}<0.05)$ & 116.5 & 523.0 & 762.0 \\
\hline $\mathrm{CV}(\%)$ & 5.4 & 5.5 & 5.9 \\
\hline
\end{tabular}

and improvement of soil properties.

All the organic sources recorded at par results. Though vermicompost significantly stimulates the growth of cereals such as rice (Bhattacharjee $e t$ al. 2001; Sunil et al. 2005) but the addition of relatively less quantity of vermicompost $\left(1.5 \mathrm{tha}^{-1}\right)$ might be the reason for $M_{3}$ being inferior to $M_{2}\left(10 \mathrm{tha}^{-1}\right)$. Bhattacharya et al. (2003) recorded the highest dry matter accumulation at 45 DAT $\left(327.1 \mathrm{~g} \mathrm{~m}^{-2}\right)$ and 90 $\left(648.4 \mathrm{~g} \mathrm{~m}^{-2}\right)$ DAT with the application of 7.0t FYM $\mathrm{ha}^{-1}$.

Combined application of organics along with RDF recorded significantly higher dry matter accumulation over RDF alone $\left(\mathrm{M}_{1}\right)$. The beneficial effect of organic manures like green manuring, FYM and vermicompost on dry matter yield was reported earlier by Maskina et al. (1985), Kandasamy and Ramasamy (1998) and Murali and Setty (2004) respectively. Investigators (EL-Agodi et al. 2011) indicated that the application of FYM increased plant growth and the dry matter production. Vermicompost also had a positive effect on vegetative growth, stimulating shoot and root development (Edwards et al. 2004).

Significant increase in growth characters (tiller number per unit area and plant height) due to combined application of organics and RDF might have resulted in increased photosynthesis and production of photosynthates which finally transformed into higher number of panicles per unit area and thereafter higher accumulation of dry matter (Rani and Sukumari, 2013). Singh et al. (2000) also reported significant improvement in dry matter accumulation of rice with increasing nutrition on account of better growth and development of the plant. The soil available nutrient status might have helped in enhancing leaf area, which thereby resulted in higher photo-assimilation and more dry matter accumulation (Swarup and Yaduvanshi 2000; Yadana et al. 2009).

\section{Grain yield}

Critical examination of the data Table 6 indicated that the grain yield of rice was significantly increased due to application of organics along with RDF over RDF alone. However, all the organic sources were on par with each other. Application of FYM 10t ha-1 + RDF $\left(\mathrm{M}_{2}\right)$ produced the highest grain yield $\left(5694 \mathrm{~kg} \mathrm{ha}^{-1}\right)$ followed by green manuring along with $\mathrm{RDF}\left(\mathrm{M}_{4}\right)$ $\left(5589 \mathrm{~kg} \mathrm{ha}^{-1}\right)$ and vermicompost $1.5 \mathrm{tha}^{-1}+\mathrm{RDF}\left(\mathrm{M}_{3}\right)$ $\left(5417 \mathrm{~kg} \mathrm{ha}^{-1}\right)$. The situation also satisfied the conditions of Baule unit concept. The nutrient contents of FYM was $0.71,0.25$ and $0.54 \% \mathrm{~N}, \mathrm{P}_{2} \mathrm{O}_{5}$ and $\mathrm{K}_{2} \mathrm{O}$, respectively, hence 10t FYM ha ${ }^{-1}$ supplied 71, 25 and $54 \mathrm{~kg} \mathrm{~N}, \mathrm{P}_{2} \mathrm{O}_{5}$ and $\mathrm{K}_{2} \mathrm{O}^{-1}$ respectively. If only $60 \%$ was available during the first season even then FYM application gave better nutrition to crop along with residual effect which ultimately improved soil health and thereby yield. Bhattacharya et al. (2003) and Shekhar (2009) had also reported beneficial effects of FYM on yield of rice due to better nutrition of crop.

$\mathrm{M}_{2}$ treatment recorded $18.77 \%$ higher grain yield over $\mathrm{M}_{1}$ treatment. The effects of FYM and green manuring were similar and significantly increased the grain yield of rice over control (Ram et al. 2011). Green manuring or addition of FYM or vermicompost although, offered the twin benefits of soil quality and fertility enhancement but while meeting a part of nutrient need of crops, sustained the high yields. Incorporation of green manuring, FYM or vermicompost in combination with fertilizer $\mathrm{N}$ significantly increased the grain yield

Table 6.Influence of organics on yield $\left(\mathrm{kg} \mathrm{ha}^{-1}\right)$ of rice

\begin{tabular}{|c|c|c|}
\hline \multirow[t]{2}{*}{ Treatment } & \multicolumn{2}{|c|}{ Pooled data of two years } \\
\hline & Grain & Straw \\
\hline $\mathrm{M}_{1}-\mathrm{RDF}$ (Control) & 4794 & 5517 \\
\hline $\mathrm{M}_{2}-\mathrm{FYM} 10 \mathrm{tha} \mathrm{ha}^{-1}+\mathrm{RDF}$ & 5694 & 6503 \\
\hline $\mathrm{M}_{3}^{2}-$ Vermicompost $1.5 \mathrm{tha}^{-1}+\mathrm{RDF}$ & 5417 & 6048 \\
\hline $\mathrm{M}_{4}$ - Green manuring + RDF & 5589 & 6391 \\
\hline SEm \pm & 169.0 & 149.5 \\
\hline $\mathrm{CD}(\mathrm{P}<0.05)$ & 521.0 & 461.5 \\
\hline $\mathrm{CV}(\%)$ & 7.1 & 5.5 \\
\hline
\end{tabular}


of rice (Bajpaiet al. 2006).

\section{Straw yield}

Straw yield also followed the similar trend as that of grain yield during both the years of the study and ranged from 5517 to $6503 \mathrm{~kg} \mathrm{ha}^{-1}$ (Table 6).

As was noticed with grain yield, straw yield was also the highest with FYM $10 t \mathrm{ha}^{-1}+\mathrm{RDF}\left(\mathrm{M}_{2}\right)$ with $6503 \mathrm{~kg} \mathrm{ha}^{-1}$ followed by green manuring along with RDF $\left(\mathrm{M}_{4}\right)$ with $6391 \mathrm{~kg} \mathrm{ha}^{-1}$. These results were in consistent with Naing et al. (2010) who reported increased straw yields in rice with the combined application of FYM and inorganic fertilizers. This implies that by combining inorganic fertilizers with FYM farmers could reduce the need for inorganic fertilizers and still increasing their productivity. Similarly, Bodruzzaman et al. (2010) also reported that plots treated with $10 \mathrm{t} \mathrm{ha}^{-1}$ FYM plus 75\% NPKSZn produced equivalent or higher rice yields as $100 \%$ NPKSZn.

The best treatment $\left(\mathrm{M}_{2}\right)$ caused $17.9 \%$ increase in straw yield over RDF alone. Azam (1990) observed higher rice yields due to organics was mainly attributed to overall improvement in soil fertility including $\mathrm{N}$ supply. In general, use of organics in combination with chemical $\mathrm{N}$ maintained wet soil $\mathrm{NH}_{4}^{+}-\mathrm{N}$ at higher levels throughout rice growth period than inorganic sources (Manivannan and Sriramachandrasekharan, 2009). Organics with inorganic $\mathrm{N}$ supply $\mathrm{NH}_{4}^{+}-\mathrm{N}$ to the plant through continuous mineralization of organic $\mathrm{N}$ and in turn increase NUE, ultimately giving higher yield (Chakraborty et al. 1988). Studies of Motavalli et al. (1994) revealed that FYM had considerable positive effect on the physical properties of the soil, which might have translated into an increase in straw yield.

\section{$\mathrm{N}$ uptake by rice}

Irrespective of growth stage of rice, the treatments those received organics along with the $\operatorname{RDF}\left(\mathrm{M}_{2}, \mathrm{M}_{3}\right.$ and $\mathrm{M}_{4}$ ) significantly increased the $\mathrm{N}$ uptake over the treatment that received RDF alone $\left(\mathrm{M}_{1}\right)$. Among the organics the highest $\mathrm{N}$ uptake by plant was recorded in the treatment $\mathrm{M}_{2}$ with $28.5,121.2,143.5 \mathrm{~kg} \mathrm{ha}^{-1}$ at 30 , 60,90 DAT but on par with each other Table 7. Similar trend was observed in case of $\mathrm{N}$ uptake by rice straw and grain. These results were in agreement with the findings of Verma (1991) who found that incorporation of FYM significantly increased the $\mathrm{N}$ uptake of seed and straw compared to other composts. Hossain et al. (2010) also reported higher $\mathrm{N}$ uptake in rice with FYM application over no fertilizer and inorganic fertilizers application.

The highest $\mathrm{N}$ uptake was associated with treatments of NPK applied through organics $+100 \%$ NPK. This might be due to added fertilizers, FYM, green manuring or vermicompost as a better availability source of $\mathrm{N}$ in soil to rice crop. Poor availability and higher loss of nutrients under RDF alone resulted lower uptake. The favourable effect of green manuring and FYM in soil and thereby removal of NPK through plant uptake by upland rice was earlier reported by Gupta $e t$ al. (2006).

\section{$P$ uptake by rice}

Results pertaining in Table 8 indicated that the $\mathrm{P}$ uptake at 30 DAT, 60 DAT, 90 DAT and maturity was significantly influenced by different organic sources of nutrients and ranged from 7.6 to 11.1 and 17.8 to $24.9 \mathrm{~kg}$

Table 7.Influence of organics on $\mathrm{N}$ uptake $\left(\mathrm{kg} \mathrm{ha}^{-1}\right)$ at different growth periods of rice

\begin{tabular}{llllll}
\hline Treatment & \multicolumn{5}{c}{ Pooled data of two years } \\
\cline { 2 - 6 } & \multicolumn{5}{c}{ N uptake } \\
\cline { 2 - 6 } & 30 DAT & 60 DAT & 90 DAT & Straw & Grain \\
\hline$M_{1}-$ RDF (Control) & 20.4 & 92.2 & 103.7 & 50.2 & 58.6 \\
$M_{2}$ - FYM 10t ha ${ }^{-1}+$ RDF & 28.5 & 121.2 & 143.5 & 68.4 & 84.8 \\
$M_{3}$ - Vermicompost 1.5t ha ${ }^{-1}+$ RDF & 26.9 & 110.5 & 134.2 & 62.5 & 78.1 \\
$M_{4}$ - Green manuring + RDF & 28.0 & 116.0 & 138.6 & 66.6 & 80.7 \\
SEm \pm & 1.0 & 3.9 & 5.4 & 2.0 & 3.4 \\
CD (P<0.05) & 3.2 & 12.1 & 16.6 & 6.2 & 10.5 \\
CV $(\%)$ & 8.7 & 8.0 & 9.3 & 7.4 & 10.1 \\
\hline
\end{tabular}


Table 8.Influence of organics on P uptake $\left(\mathrm{kg} \mathrm{ha}^{-1}\right)$ at different growth periods of rice

\begin{tabular}{llllll}
\hline \multirow{2}{*}{ Treatment } & \multicolumn{5}{c}{ Pooled data of two years } \\
\cline { 2 - 6 } & \multicolumn{5}{c}{ P uptake } \\
\cline { 2 - 6 } & 30 DAT & 60 DAT & 90 DAT & Straw & Grain \\
\hline$M_{1}$ - RDF (Control) & 3.5 & 14.3 & 15.1 & 7.6 & 17.8 \\
$M_{2}$ - FYM 10t ha ${ }^{-1}+$ RDF & 5.4 & 19.6 & 22.2 & 11.1 & 24.9 \\
$M_{3}$ - Vermicompost 1.5t ha ${ }^{-1}+$ RDF & 4.7 & 17.9 & 20.0 & 10.1 & 22.1 \\
$M_{4}$ - Green manuring + RDF & 5.2 & 18.8 & 21.4 & 10.6 & 23.5 \\
SEm \pm & 0.2 & 0.6 & 0.6 & 0.3 & 1.0 \\
CD (P<0.05) & 0.5 & 1.9 & 2.1 & 0.8 & 3.0 \\
CV $(\%)$ & 8.0 & 7.7 & 7.1 & 6.3 & 9.9 \\
\hline
\end{tabular}

ha ${ }^{-1}$ by rice straw and grain, respectively.

Irrespective of growth stage of rice the treatments those received FYM, vermicompostor green manuring along with the RDF significantly increased the $\mathrm{P}$ uptake over the treatment received RDF alone. The highest $\mathrm{P}$ uptake at all growth stages of rice was observed in the treatment $\mathrm{M}_{2}$ with $5.4,19.6,22.2 \mathrm{~kg}$ ha $^{-1}$ at 30, 60 and 90 DAT of rice respectively.Second highest of $\mathrm{P}$ uptake was recorded by green manure incorporated treatment $\left(\mathrm{M}_{4}\right)$ with $5.2,18.8,21.4 \mathrm{~kg}^{-}$ ${ }^{1}$ at 30, 60, 90 DAT of rice plant, respectively. The higher $P$ uptake attributed to the increased $P$ availability and increased root growth of the crop (Tilahun et al. 2013). According to Aziz et al. (2010) root growth in plants receiving FYM was higher and hence would increased nutrient uptake. Yassen et al. (2010) further suggested that FYM application increased the transfer of elements between the solid phase and soil solution which again could be a reason for the higher nutrient uptake. It was also indicated that the activity of soil microorganisms under higher FYM applications might had led to increased nutrient uptake (Yassen et al 2010).

\section{$\mathrm{K}$ uptake by rice}

Results presented in Table 9 revealed that $\mathrm{K}$ uptake at 30 DAT, 60 DAT, 90 DAT and maturity was significantly influenced by different organic sources of nutrients and followed the similar trend of $\mathrm{P}$ uptake by rice at various growth stages. K uptake ranged from 33.0 to $46.6 \mathrm{~kg}$ ha $^{-1}$ at 30 DAT, 142.3 to $203.7 \mathrm{~kg} \mathrm{ha}^{-1}$ at 60 DAT, 151.1 to $209.3 \mathrm{~kg} \mathrm{ha}^{-1}$ at $90 \mathrm{DAT}, 91.2$ to $121.8 \mathrm{~kg} \mathrm{ha}^{-1}$ by straw and 17.3 to $24.2 \mathrm{~kg} \mathrm{ha}^{-1}$ by grain at maturity. The highest $\mathrm{K}$ uptake by rice was recorded by the treatment $\mathrm{M}_{2}$. Singh et al.(2004) reported that application of 10t FYM $\mathrm{ha}^{-1}$ in rice-wheat system significantly increased $\mathrm{K}$ uptake by 7.6 per cent over control. Pradeep et al. (2012) also concluded that application of recommended dose of fertilizer + FYM @ 10t ha ${ }^{-1}$ recorded significantly higher potassium $\left(94.0 \mathrm{~kg} \mathrm{ha}^{-1}\right)$ uptake.

Table 9. Influence of organics on K uptake (kg ha-1) at different growth periods of rice

\begin{tabular}{|c|c|c|c|c|c|}
\hline \multirow{4}{*}{ Treatment } & 30 DAT & 60 DAT & 90 DAT & Straw & Grain \\
\hline & \multicolumn{5}{|c|}{ Pooled data of two years } \\
\hline & \multicolumn{5}{|c|}{ K uptake } \\
\hline & 30 DAT & 60 DAT & 90 DAT & Straw & Grain \\
\hline M1 - RDF (Control) & 33.0 & 142.3 & 151.1 & 91.2 & 17.3 \\
\hline M2 - FYM 10t ha-1 + RDF & 46.6 & 203.7 & 207.6 & 121.5 & 24.2 \\
\hline M3 - Vermicompost $1.5 \mathrm{t}$ ha-1 + RDF & 43.9 & 176.1 & 190.5 & 110.0 & 22.5 \\
\hline M4 - Green manuring + RDF & 45.6 & 186.6 & 209.3 & 118.6 & 23.0 \\
\hline $\mathrm{SEm} \pm$ & 1.7 & 6.3 & 8.5 & 3.7 & 1.0 \\
\hline $\mathrm{CD}(\mathrm{P}<0.05)$ & 5.2 & 19.4 & 26.3 & 11.3 & 3.2 \\
\hline $\mathrm{CV}(\%)$ & 9.0 & 8.0 & 10.1 & 7.4 & 10.0 \\
\hline
\end{tabular}


Duhan et al. (2001) observed that application of GM, in general, increased the $\mathrm{K}$ uptake in rice grain and straw.

Data collected on plant height, dry matter yield, yield attributes, grain yield and straw yield of rice were recorded significantly higher in the treatment $\mathrm{M}_{2}$ $\left(100 \%\right.$ NPK in combination with FYM @ $\left.10 \mathrm{t} \mathrm{ha}^{-1}\right)$. However, it was on par with that of application of green manure along with $100 \%$ NPK. So green manure in situ with Dhaincha may be used for an alternative organic source of nutrients to the FYM.

\section{REFERENCES}

Azad BS and Lehria SK 2001. Yield maximization of rice through integrated nutrient management under irrigated conditions. Ann Agric. Res. New Series 22: 471-475.

Azam F 1990. Comparative effects of organic and inorganic sources applied to a flooded soil on rice yield and availability of N. Plant Soil 125: 255-262.

AzizT, Ullah S, Sattar A, Nasim M, Farooq M and Mujtabakhan M 2010. Nutrient availability and maize (Zea mays) growth in soil amended with organic manures. Int. J. Agric. Biol. 12: 621-624.

Bajpai RK, Chitale S, Upadhyay SK and Urkurkar JS 2006. Long-term studies on soil physico-chemcal properties and productivity of rice-wheat system as influenced by integrated nutrient management in Inceptisol of Chhattisgarh. J. Indian Soc. Soil Sci. 54: 24-29.

Bhattacharjee G, Chaudhuri PS and Datta M 2001. Response of paddy (Var. TRC-87-251) crop on amendment of the field with different levels overmicompot.AsianJ. Microbiol.Biotechnol. Environ. Sci. 3(3): 191-196.

Bhattacharya SP, Sitangshu S, Karimadkar AJ, Bera PS, Latika M, Sarkar S and Mandal L 2003. Effects of humic acid (earth) on the growth and yield of transplanted summer rice.Environ.Ecol.21: 680-683.

Bodruzzaman M, Meisner CA, Sadat MA and Hossain MI 2010.Long-term effects of applied organic manures and inorganic fertilizers on yield and soil fertility in a wheat-rice cropping pattern.19th World Congress of Soil Science, Soil Solutions for a Changing World 1-6 August 2010, Brisbane, Australia. P 23-44.

Chakraborty PK, Mandal LN and Anup M 1988. Organic and chemical sources of nitrogen its effect on nitrogen transformation and rice productivity under submerged condition. J. Agric. Sci. (Cambridge) 111:91-94.

Duhan BS, Kumar V, Singh N, Khera AP, Kumar V and Singh N 2001.Effect of manuring on the yield and uptake of potassium in rice.Crop Res. Hissar 22: 330-334.

Edwards CA, Domínguez J and Arancon NQ 2004. The influence of vermicomposts on plant growth and pest incidence. In: Shakir SH and Mikhaïl WZA (Eds). Soil Zoology for Sustainable Development in the 21 st century, 397-420, Cairo.

El-Agodi MWM, El-Zehery TM and Hasnaa LL 2011. Effect of chicken manure and gypsum of sugar beet (Beta vulgaris var. saccharifora) under saline conduction.J.Soil Sci. Agric.Engg.Mansoura University, 2: 701-716.

El-Shouny MM, El-Shikha SA and El-WarthA 2008. Impact of farm yard manure and some mineral fertilizers on some soil properties and its productivity of wheat. Minufiya J. Agric. Res. 33:1249-1267.

Gazia EAE 2001: Effect of farm yard manure, gypsum and nitrogen on sugar beet yield and NPK uptake. Minufiya J. Agric. Res. 26: 1117-1125.

Gupta V, Sharma RS and Vishwakarma SK 2006. Long-term effect of integrated nutrient management on yield sustainability and soil fertility of rice (Oryza sativa) - wheat (Triticumaestivum) cropping system. Indian J. Agron.51: 160-164.

Hemalatha M, Thirumurugan V and Balasubramanian $\mathrm{R}$ 2000.Effect of organic sources of nitrogen on productivity, quality of rice (Oryza sativa) and soil fertility in single crop wet lands. Indian J. Agron. 45: 564-567.

Hossain AT, Rahman F, Saha PK and Solaiman ARM. 2010. Effects of different aged poultry litter on the yield and nutrient balance in boro rice cultivation. Bangladesh J. Agric. Res. 35(3): 497-505.

Jackson ML 1973. Soil chemical analysis. Prentice Hall of India Private Ltd., New Delhi, pp. 134-182.

Kandasamy OS and Ramasamy A 1998. Influence of organic and inorganicfertilization and plant density on production potential of rice-ricecropping system. Madras Agric. J. 85: 604-607.

ManivannanR and Sriramachandrasekharan MV 2009.Effect of organic sources and urea on $\mathrm{N}$ transformation and yield of lowland rice grown in clay loam soil. Res. J.Agric. Biol. Sci. 5: 1104-1109.

Maskina MS, Sandhu PS and Meelu OP 1985. Effect of 
integrated use of organic and inorganic nitrogen sources on growth and nutrient composition of rice seedlings.Oryza 22: 11-16.

Miller HB 2007. Poultry litter induces tillering in rice. J. Sustain. Agric. 31: 1-12.

Mirza H, Ahamed KU, Rahmatullah NM, Akhter N, Nahar K and Rahman ML 2010. Plant growth characters and productivity of wet land rice (Oryza sativa) as affected by application of different manures. Emir. J. Food Agric. 22: 46-58.

MohanaRao P, Prasad PRK, RavindraBabu P, NarasimhaRaoKL and SubbaihG 2016. Influence of different sources of nutrients on available nutrient status of soil after harvest of rice crop. Andhra Agric. J. 63:121-127.

Motavalli PP, Singh RP and Anders MM 1994. Perception and management of farm yard manure in the semiarid tropics of India. Agric. Syst. 46: 189-204.

Muhammad I 2008. Response of wheat growth and yield to various levels of compost and organic manure.Pakistan J. Bot. 40: 2135-2141.

Murali MK and Setty RA 2004. Effect of fertilizer, vermicompost and triacontanol on growth and yield of scented rice. Oryza 41: 57-59.

Naing A, Banterng P, Polthanee A and Treloges V 2010.The effect of different fertilizers management strategies on growth and yield of upland black glutinous rice and soil property.Asian J. Plant Sci. 9: 414-422.

Olsen SR, Code CL, Watanable FS and Dean LA 1954. Estimation of available phosphorus in soils by extraction with sodium bicarbonate.UnitedStates Development Agency Circular Number 939.

Patra AK, Nayak BC and Mishra MM 2000. Integrated nutrient management in rice (Oryza sativa) - wheat (Triticumaestivum) cropping system. Indian Journal of Agronomy 45(3): 453-457.

Pradeep G, Channanaik D, Rajanna GA, Sannathimmappa HG, Ramesha YM and Veeresha 2012. Economics and nutrient uptake of rice (Oryza sativa) as influenced various levels of FYM and cattle urine application in Bhadra command area of Karnataka. Crop Res. 43: 10-14.

Raju RA and Reddy MN 2000.Integrated management of green leaf compost, crop residues and inorganic fertilizers in rice (Oryza sativa) to rice system. Indian Journal of Agronomy 45(4): 629-635.

Ram M, Dawari MR and Sharma SN 2011. Organic manures and fertilizers on basmati rice under organic farming of rice wheat cropping system. Int. J. Agric. Crop Sci. 3(3): 76-84.

Rani S and Sukumarim P 2013. Root growth, nutrient uptake a2nd yield of medicinal rice njavara under different establishment techniques and nutrient sources. Am. J. Plant Sci. 4:1568-1573.

Sarker MAR, Pramanik MYA, Faruk, GM and Ali 2004. Effect of green manures and levels of nitrogen on some growth attributes of transplant aman rice. Pakistan J. Biol. Sci. 7: 739-742.

Sharma AR and Mittra BN 1988. Effect of green manuring and mineral fertilizer on growth and yield of crops in rice based cropping on acid lateritic soil. J. Agric. Sci. 110: 605-608.

Shekhar J, Mankotia BS and Dev SP 2009.Productivity and economics of rice (Oryza sativa) in system of rice intensification in north western Himalayas. Indian J.Agron. 54: 423-427.

SiddaramMurali K, Manjunatha BN, Jagadeesha N, Basavaraja MK and Ramulu 2011.Effect of nitrogen levels through organic sources on dry matter production and nutrient uptake of irrigated aerobic rice (Oryza sativa L.).Mysore J. Agric. Sci.45: 191193.

Singh AK, Amgain LP and Sharma SK 2000.Root characteristics, soil physical properties and yield of rice (Oryza sativa) as influenced by integrated nutrient management in rice-wheat system. Indian J. Agron.45: 217-222.

SinghSK, Verma SC and Singh RP 2004.Residual effect of organic and inorganic sources of nutrients in lowland rice on succeeding lentil.Indian J. Agric. Res. 38: 121-125.

Singh YV and Mandal BK 1997.Nutrition of rice through azolla, organic materials and urea. Indian J.Agron . 42:626-633.

Subbiah BV and Asija CL 1956.A rapid procedure for the estimation of available nitrogen in soils.Curr. Sci. 25:259-260.

Sunil K, Rawat CR, Shiva D and Suchit KR 2005.Dry matter accumulation, nutrient uptake and changes in soil fertility status as influenced by different organic and inorganic sources of nutrients to forage sorghum (Sorghum bicolor). Indian J. Agric. Sci. 75: 340-342.

Swarup A and Yaduvanshi NPS 2000.Effect of integrated 
nutrient management on soil properties and yield of rice in alkali soils. J. Indian Soc. Soil Sci. 48: 279282.

Tilahun TF, Nigussie DR, Wondimu B and Setegn G 2013. Effect of farm yard manure and inorganic fertilizers on the growth, yield and moisture stress tolerance of rainfed lowland rice. Am. J. Res.Commun. 1: 274301.

Verma TS 1991. Influence of Lantana, Eupatorium and Farm yard manure on paddy crop. Oryza 28: 177-183.

Watanabe FS and Olsen SR 1965. Test of ascorbic acid method fordetermining phosphorous in water and sodium bicarbonate extracts of soil. Soil Sci. Soc. Am. J. 29:677-78.
Yadana KL, Aung KM, Takeo Y and Kazuo O 2009. The effects of green manure (Sesbania rostrata) on the growth and yield of rice. J. Fac. Agric. Kyushu Univ. 54: 313-319.

Yassen A, Khaled A, Sahar SM and Zaghloul M 2010.Response of wheat to different rates and ratios of organic residues on yield and chemical composition under two types of soil. J. Am. Sci. 6:858-864. 